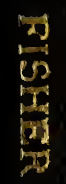

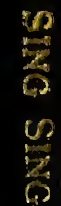

倠

$-4$

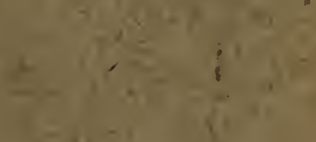


HARVARD UNIVERSITY.

LI B RA R Y

OF TILE

MUSEUM OF COMPARATIVE ZOÖLOGY.

33356

GIFT OF

Outran Barge

March 19.1909 . 
(From The Observer, Portland, Conn., Vol. Vil., No. ;, May, 1896.)

THE MAMMALS OF SING SING, N. Y.

By A. K. Fisher, M. D.

AUTHOR'S EDITION: 



\section{The Mammals of Sing Sing, New York.}

BY A. K. FISHER, M. D., WASHINGTON, D. C.

$7 \mathrm{HE}$ village of Sing Sing is situated on the east bank of the Hudson

River a little more than thirty miles north of New York City, and about two miles south of the true mouth of the Croton River.

The famous Tellers (now Croton) Point is in full view from the village and forms a picturesque peninsula several miles in extent between the broad cove-like expansion of the Croton and Hudson Rivers.

The territory covered by the present paper includes the townships of Ossining, Mount Pleasant, and portions of New Castle, Yorktown, and Cortlandt, all situated east of the Hudson.

The surface of the country is very rough and uneven and is made up for the most part of nearly parallel series of rugged knolls or broken ridges which have a general trend from northwest to southeast. Some of the eminences rise to nearly eight hundred feet above the surface of the Hudson, which is practically at sea-level. The prevailing rocks are an imperfect granite and gneiss with outcroppings of dolomitic limestone. The principal valley lands and less rugged hills have been claimed for agriculture and grazing purposes, yet the greater part of the surface is still covered by forests and undergrowth.

The streams and springs are numerous, though the majority of the ponds are of artificial origin.

Excepting the red cedar (Juniperus virginiana) the hemlock (Tsuga canadensis) is the most common evergreen, and still covers many of the ridges. On Croton Point there stands (or did a few years since) several fine examples of this noble tree, with trunks twelve to fifteen feet in circumference. The pitch-pine (Pinus rigida), yellow-pine ( $P$. mitis), and the ground hemlock (Taxus) occur, the latter species as far as we know, only along the cold west bank of the Croton. In this connection it may be of interest to state that several herbaceous plants and two shrubs, the moosewood (Acer pennsylvanicum) and red berried elder (Sambucus pubens) occur in this region only on Croton Point-a locality of great fascination to the botanist.

The deciduous woods and groves are rich in variety, containing many common species as well as stragglers from the north or the south. The drier and upland woods are composed of chestnut, red, white, and black oaks, black birch, tulip, beech, iron wood (Ostrya) and flowering dogwood, while those of the swamps and lowlands are made up of maple, pepperidge (Nyssa), swamp white oak, ash, elm, hornbeam (Carpinus), yellow birch and many others.' Besides all these a few 
like the wild cherry, sassafras, sycamore, butternut, locust, and numerous shrubs assist in forming the scattered groves and roadside thickets.

As might be expected with all the protection afforded by rocky ledges, forests, undergrowth, briers, and other retreats of nature, the smaller mammals are well represented in the region.

The following list of mammals is based on observations extending over a considerable number of years, and made for the most part prior to the year 1885 .

Didelphis virginianus. Opossum. - Strictly speaking this animal should not be included in the present list, because as far as known it has never been taken in Westchester County. Nevertheless it is tolerably common in Rockland and Orange Counties, two or three miles to the westward, and is only prevented from entering our domain by that ideal but insuperable barrier, the Hudson River. This broad, deep, powerful stream so dreaded by the old Dutch sailors of New Amsterdam, seems likewise to be feared and avoided by the equally slow-going opossum.

Sorex personatus. COMmON SHREw.-The common shrew is rather rare and is the only one of the long-tailed species found in the neighborhood. Its scarcity however may be only apparent, and due wholly or in part to our lack of skill in former days, in trapping it successfully. The majority of specimens were secured from birds of prey. On one occasion, April I8, I885, two were found in the stomach of a red-tailed hawk. It is probable that the little animal dwells usually in cool boggy or sphagnum swamps, though it has been taken in dry upland thickets in other localities.

Blarina brevicauda. SHORT-TAILED SHREw.-A common species. Almost anywhere in the woods its tunnels may be found running hither and thither under the matting of dry leaves or old decayed logs. In the open meadows it is less common though occasionally found, attracted there no doubt by the meadow mice or other favorite food.

Scalops aquaticus. Common Mole.-Common in the meadows and lawns. It is when inhabiting the latter localities that we hear the most complaint about the mole. This is especially true where the soil is so light that the upheaved grass roots along the tops of the wandering tunnels are endangered from lack of moisture. As far as known the mole is wholly insectivorous and does not molest vegetables of tubers of any kind, though it may indirectly injure young plants by burrowing near them. As soon as the frost leaves the ground in the spring the moles follow the earth worms towards the surface, and seem more active in extending their galleries than at any other time of year. 
It is difficult to determine how many litters of young they have in a year. I have taken two young three-quarters grown on May $3 \mathrm{I}$, and on the same day captured a female containing three embryos, having a total weight of only thirteen grams.

Condylura cristata. STAR-NOSED MOLE. - The star-nosed mole is far less common than the preceding species, and usually inhabits wet meadows near streams, though occasionally taken in dry soil. The galleries of the star-nosed mole, unlike the uniformly elevated ridges of the common species, consist of a series of a dozen or more hills or dirt mounds without visible connections between them. The difference in the construction of the tunnels of the two species is easily accounted for. The common mole living in light and yielding soil and near the surface can force any extraneous dirt to one side or the other, whereas the star-nosed mole dwelling in heavy wet soil deeper underground, is obliged to push the accumulations through holes to the surface, thus forming the hills. These hills are a few inches high and five or six inches across, and in general appearance somewhat resemble those of the pocket gophers of the West.

On April r6, r884 I was fortunate enough to see the nest of this mole. A neighbor was repairing a woodshed which stood near a low meadow, and in removing some old timber unearthed the nest. It was placed under a layer of six inches or more of old chips, was composed of dry grasses and leaves and contained five young. These were about as large as full grown short-tailed shrews and weighed from 25 to 28 grams (about one ounce) each. They were covered with short thick hairs, and the nasal fringes were well developed.

Strange as it may appear this animal is an expert swimmer and glides through the water with perfect ease.*

Vespertilio lucifugus. BLUNT-NOSED BAT.-Rare. Out of the hundreds of bats collected only one of this species was ever secured, which was on June 9, I 884 .

Vesperugo fuscus. Brown BAT.-Common. Seen from the first warm evenings of April until November. On November I 2, I884, one was seen flying about the streets, hunting insects at two o'clock in the afternoon.

Vesperugo noctivagans. SILver-HAIRED BAT.-Tolerably common. Usually seen until after the heavy frosts of the middle of October. The majority of young are born during the week beginning June 20 . The usual number of young is two, though occasionally only one. On June 24, 1884, Mr. Howard Acker found sixteen females with twenty-

\footnotetext{
* See note of one seen swimming June 7, I885. (American Nat. XIX, Sept. I885, 895.)
} 
five young (from one to three days old) under the siding of an old house. They were nestled closely together and the young were clinging to their parents.

Vesperugo georgianus. Georgian Bat.-The commonest bat. On warm summer evenings when the conditions of atmosphere and insects are just right, hundreds may be seen flying back and forth over fields or lakes, busily engaged in collected their diminutive prey. The young, which as far as we know are always twins, are born about the middle of June. Some remarks we made years ago* on Vespertilio subulatus really refer to this species, the former never having been taken at Sing Sing.

Atalapha cinerea. HOARY BAT.-On the evening of October $\mathrm{I}, \mathrm{I} 883$. one of these beautiful bats was seen flying about a lawn, where it was well identified. Scarcely two months before the writer had become perfectly familiar with the appearance and flight of the species, having seen and killed numbers of them in the edge of the Adirondack region. Consequently he feels reasonably sure that the indentification is correct. A friend who had examined a number of specimens was sure he saw one flying along the edge of the river, Sept. 27, 188.5 .

Atalapha borealis. RED BAT.-Next to the little Georgian bat the red bat is the commonest species. It is one of the first to appear in the evening and towards the end of the season hardly waits for the sun to set before starting out in search of food.

The female brings forth usually two, sometimes three young, which appear about the second week in June. The period of gestation therefore is a little over ten months, as the mating season is at its height during the first week in August. The red bat is more arboreal than the other species and is often seen during the day hanging among the foliage of the trees.

Tamias striatus. CHIPMUNK.--Common. Just as soon as the warm days of March come the chipmunk leaves its winter retreat and sallies forth At such times if the snow still remains on the ground its tracks may be seen about the old logs and fence rows. Many kinds of nuts, seeds, and berries as well as insects are eaten by this little squirrel. It is tireless in its search for food, and displays as much energy while collecting the minute seeds of grasses and other small plants as the large nuts of the butternut and hickory.

Arctomys monax. WooDchuck.-Common. As many as a dozen have been seen at one time in a large meadow. Although they occasionally come out of their burrows on warm days in February, it is not

*Forest \& Stream XVI, 25, July 2I, I88I, 490. 
until the micidle of March, when the grass and clover begin to sprout that they are seen at all commonly. By the first of June young the size of gray squirrels are to be seen about the meadows. On July ıo, I 884 , one in black pelage was captured.

Sciurus niger cinereus. NORTHern Fox SquirRel.-Mr. Gilbert C. Merritt once informed me that he had killed several fox squirrels in the Chappaqua hills about the year $185^{\circ}$. Of late none have been heard of, even in that wild region.

Sciurus carolinensis leucotis. GRAY SQUIRREL.-Periodically common. Some years hundreds are killed during the open season, while on the following year not over a dozen will be secured. They are excessively fond of hickory nuts, and early in September begin to eat the still partially green nuts. It is at this time that they are most easily taken. A.t daybreak the hunter attracted by the sound of falling shucks can easily approach under cover of the thick canopy of leaves, locate the animal by the moving branches, and shoot it before his presence is known.

Sciurus hudsonicus. RED SQUIRREL.-Common. With the exception of the house cat and sharp-shinned hawk, the red squirrel probably kills more young birds than any other animal. Repeatedly I have seen them eating young robins, and have killed several while attempting to plunder the wren boxes near the house. About the middle of April the young are born, and are usually three or four in number. When the animals are numerous they do considerabledamage to the pear and apple crop by cutting off the green fruit for the purpose of eating the seeds. In the winter while searching for food they form extensive runways in the nut groves under the snow, and when spring comes and enough of the snow has melted so these minature paths can be seen, they look not unlike a railroad model of one of our populous states.

Sciuropterus volucella. Flying SQUiRREL.-Common. In the day time they remain quietly in hollow trees, bird houses, out buildings, hay lofts, or garrets of houses, and as dusk approaches come out of their hiding places and start off on foraging expeditions.

The animal is unusually attractive and when taken early in life makes a tame and interesting pet. Sometimes, as with red and gray squirrels, litters of young appear late in the fall. On one occasion a friend of the writer found four young scarcely as large as house mice on October I 7 .

Mus musculus. House Mouse.-Common in the corn and rye fields as well as around buildings.

Mus decumanus. Common Rat.-Common.

Peromyscus leucopus. White-footed Mouse.-Common. This 
mouse is found everywhere in the woods and groves about fence rows, and in fall and winter ventures to the stacks and out houses. It is a good climber and often makes its home in an old bird's nest, after covering the top over with fine grass and•lining it with hair or feathers.

Microtus pennsylvanicus. Meadow Vole. - Very common in the low wet meadows, especially near streams. In fall when the green meadows become brown, it sometimes wanders to the cornfields where the bunches of stalks furnish it with food as well as shelter. When over abundant, as it sometimes is, this little mammal is most destructive to crops and small fruit trees. Young orchards containing hundreds of trees have been killed in one winter by being girdled beneath the surface of the snow by these pests. Hawks and owls are its most relentless enemies, and if it were not for the criminal persecution of these noble birds, they would keep the mice well in check.

Microtus pinetorum. PINE Mouse. - Tolerably common. Its favorite resorts are the dry grassy hillsides more or less grown up with small bushes and briers, and old orchards. containing weeds, matted grass, and young saplings. Most of the specimens secured were taken from the store houses of the screech owl.

Fiber zibethicus. Muskrat.-Common in the salt meadows, tide creeks and all the streams and ponds. As many as ten have been taken in an ordinary box trap in one night.

Zapus hudsonicus. JumPing Mouse. Tolerably common. Usually found in the tall grass of wet meadows near streams, but occasionally observed in dry pastures.

Lepus sylvaticus. Cottontail.-Common. Although hundreds are killed every winter neverthless they appear to be just as common at the present time as twenty years ago.

Cariacus americamus. DeER. - The last deer killed near Sing Sing was a doe shot by Mr. Chas. Acker on December ro, r86r. It had been seen on severaloccasions, at various places, and was finally secured in a tract known as Bacon's Woods.

In a letter from my lamented friend, George Ayles, dated July I, I889, after describing a fishing trip made a few days previously to Colabaugh Pond, a small body of water five miles north of Sing Sing, he says, "At the place where we put up near the pond, the farmer told me that he had seen a fine deer feeding in the meadows near his house that morning. It must be the same that has been in the vicinity for the past year." I never heard that this deer was killed and hope it escaped.

Lynx rufus. WildCat.-It is probable that a few wildcats still remain in the wilder parts of the region. The last one killed in the 
neighborhood, as far as we know, was shot by a Mr. Reynolds at Katonah, in March, r880. It was killed while running before the hounds, and weighed about thirty pounds.

Vulpes pemisylvanicus. RED Fox.-Common. This locality is an ideal one for foxes. It contains enough wild uncultivated land to insure their safety and still is in close proximity to farming country where food is easily procured.

In on€ week in December, I88I, a hunter killed seven foxes, and as far as we can learn foxes have not diminished materially up to the present time. The mating season is probably in the latter part of January as at that time they are seen running in pairs.

After long and careful study of their movements, as recorded by the tracks in the snow, the question arises whether they are not of more value to man than otherwise. Surely they destroy myriads of meadow voles and other mice as well as rabbits and young woodchucks.

Urocyon virginianus. GRAY FOx.-Not uncommon, but much rarer than the red fox. Judging from the number killed, the red fox is five times more common than the gray. In fox hunting the latter species is always considered far inferior, and is never able to give the hounds such a tiresome chase as its agile and cunning relative, the red fox.

Mephitis mephitica. Skunk.-Common. A very beneficial animal and one that should be carefully protected as it lives largely on injurious insects and mice. Although it is accused of killing chickens and maybe some times justly, nevertheless an old one and her six young lived in the wall of our chicken yard and neither eggs nor chickens were missed. If the scent sacs are removed before the young is half grown, it can be made a gentle and attractive house pet, as cleanly and more affectionate than any cat.

Lutra canadensis. OTTER.-Probably it still rarely occurs at Croton Lake and River. The last specimen we have any record of, was taken in the tide creeks in Croton Point, about 1880.

Lutreola vison. Mink.-Common along all the larger streams and ponds.

Putorius noveboracensis. WEASEL. - Tolerably common. This is another animal which "on account of its occasional inroads on poultry" is most ruthlessly destroyed whenever opportunity offers. Its chief food is the smaller rodents, and many times has the little animal been seen carrying a mouse in its mouth.

Once we remember of finding a weasel, shot by some one, and beside it lay a meadow mouse it had been carrying. On May 29, r878, while resting in a shady nook where a stone wall crossed a small stream, Mr. George Ayles and the writer heard a noise which sounded almost 
exactly like the baying of a pack of hounds in the distance. The resemblance was remarkably close and in our imagination we heard the deep voice of the veteran leader mingled with those of his excited band. If memory is not at fault we wondered why hounds were running at that time of year. A slight rustle near by attracted our attention and to our surprise there stood five or six weasels at different places along the wall, each making a noise, the combination of which we had mistaken for the baying of dogs. My friend who sat near the wall raised his collecting pistol and shot at one, when almost immediately the rest made a rush at him and it was several moments before they could be driven off.

Procyon lotor. RACcoon.-Common. Found everywhere but more commonly in the swamps and along streams. During the time corn is in the milk and while chestnuts are falling, coon hunting is quite a pastime.

Phoca vitulina. HARBOR SEAL.-Almost every spring one or more seals are seen about the time the ice is breaking up in the river. On March II, I 884 an adult male was secured in the cove.

Phocana communis. Porpolse.-Common in the river during the summer months, occasionally coming into the shallow water of the cove. 

- 


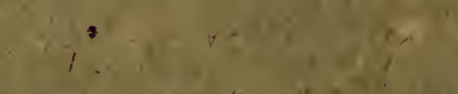

$\therefore$

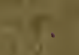
$15 \theta^{\circ}$
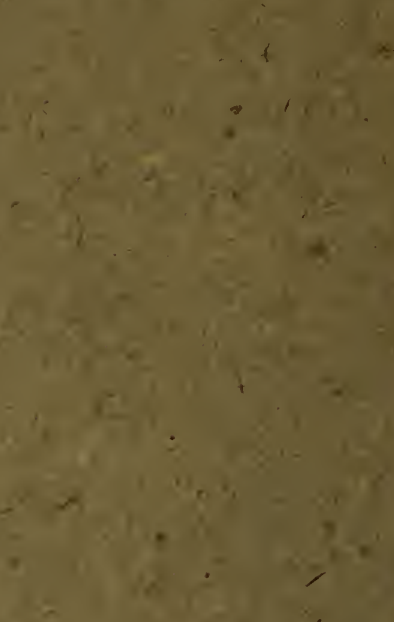

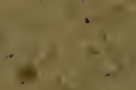

